\title{
Efektifitas Pembuatan Kompos Limbah Pabrik Teh Hijau (Tea Fluff) Menggunakan EM4 dan Pupuk Kandang Sapi
}

\author{
Restu Wulansari ${ }^{1}$, Anni Yuniarti ${ }^{2}$, dan Erdiansyah Rezamela ${ }^{1}$ \\ 1)Pusat Penelitian Teh dan Kina, Gambung, Pasirjambu, Kabupaten Bandung, 40010, Indonesia \\ 2)Departemen Ilmu Tanah dan Sumberdaya Lahan, Fakultas Pertanian Universitas Padjadjara \\ Jl. Raya Bandung Sumedang Km 21 Jatinangor
}

Korespondensi: restuwulan_sari@yahoo.com

\begin{abstract}
One of the way to use green tea factory waste (tea fluff) as a source of plant nutrients is in the form of compost. The aim of this research was to get the appropriate composition of composting of green tea factory waste using a combination of EM4 and cow manure and composted for 5 weeks (35 days). This research was designed in randomized block with 6 treatments and four replications. Compositions of tea fluff and manure compost consisted of: $P 1=$ Control; $P 2=$ Tea Fluff + cow manure (1: 1); P3 = Tea Fluff + cow manure (1: 2); P4 = Tea Fluff + cow manure (1: 3); P5 = Tea Fluff + cow manure (2: 1); and P6 = Tea Fluff + cow manure (3: 1). Data related to composting process such as physical quality (color, texture, and odor) and chemical analysis ( $\mathrm{pH}, \mathrm{C}$-organic, $\mathrm{N}$-total and $\mathrm{C} / \mathrm{N}$ ratio) were taken. Based on the results of daily temperature and $\mathrm{pH}$ fluctuations, composting proces ran normally. Based on the results of chemical analysis, the parameters of $\mathrm{pH}$, organic $\mathrm{C}$ and $\mathrm{N}$-total compost showed significant differences. Within 5 weeks, all compost parameters that have been analyzed chemically and the results has fulfilled the quality standards according SNI 19-7030-2004 standard. Combination of tea fluff:cow manure (3: 1) showed the highest C-organic and $N$-total results among all treatments.
\end{abstract}

Key words: EM4, cow manure, tea fluff compost, tea plantation

\section{PENDAHULUAN}

Kompos adalah pupuk organik hasil dekomposisi bahan organik dapat meningkatkan kesuburan tanah dengan perbaikan sifat fisik, biologi dan kimia tanah. Pengomposan merupakan proses dekomposisi yang dilakukan oleh agen dekomposer terhadap sampah organik yang biodegradable (Amalia dan Widiyaningrum, 2016). Proses pengomposan yang terjadi secara alami umumnya berlangsung lambat, agar dapat dipercepat proses pengomposan telah dikembangkan teknologi pengomposan, antara lain dengan menggunakan aktivator sehingga proses pengomposan lebih cepat dan efisien (Trivana dan Pradhana, 2017; Kurniawan et. al., 2017). Komposisi bahan yang ideal untuk dikomposkan memiliki nisbah C/N sekitar 30, sedangkan kompos matang memiliki nisbah $\mathrm{C} / \mathrm{N}<20$. Standar kualitas kompos ideal tersebut mengacu kepada SNI 19-7030-2004 mengenai spesifikasi kompos dari sampah organik domestik (BSN, 2004).
Limbah pabrik teh (tea fluff) merupakan hasil sortasi dari pabrik teh hijau yang terdiri atas bahan padatan (serat) yang jumlahnya cukup banyak, sekitar 1-3\% dari produksi teh yang dihasilkan. Teh hijau merupakan hasil olahan pucuk teh tanpa proses fermentasi, yaitu dibuat dengan cara menginaktifkan enzim fenolase yang ada dalam pucuk daun teh segar, dengan pemanasan sehingga oksidasi terhadap katekin (zat antioksidan) dapat dihindari (Muningsih dan Ciptadi, 2018).

Berdasarkan hasil analisis kandungan hara hasil fermentasi limbah padat teh hijau menunjukkan adanya kandungan unsur Corganik (5,7\%), N (0,24\%), P (0,06\%), dan K $(0,69 \%)$, sedangkan kandungan hara $\mathrm{Cu}(1,63$ ppm) dan Zn (3,33 ppm). Industri pengolahan teh sangat banyak di Indonesia. Limbah padat yang dihasilkan mencapai 8-10 ton dalam setahun. Ketersediannya limbah ini cukup tinggi sehingga sangat potensial sebagai sumber bahan organik yang dapat meningkatkan kesuburan tanah dan pertumbuhan 
pucuk teh. Metodenya adalah dengan mengolah limbah padat tersebut menjadi kompos (Rahayu dan Nurhayati, 2005).

Pada proses pengomposan, sejumlah jasad hidup berperan aktif dalam penguraian bahan organik kompleks menjadi lebih sederhana (Sulistyorini, 2005). Untuk mempercepat perkembangbiakan mikroba diperlukan bioaktivator dalam pembuatan kompos, yaitu menggunakan EM4 (Effective Microorganisms 4). Pupuk kandang sapi juga dapat dijadikan bioaktivator dalam pengomposan limbah teh hijau (tea fluff). Selain kotoran ternak, pupuk buatan pabrik seperti urea bisa juga ditambahkan pada proses pengomposan (Sulistyorini 2005; Suwatanti dan Widiyaningrum, 2017).

Pupuk kandang ternak memiliki rasio $\mathrm{C} / \mathrm{N}$ sebesar 11,3. Hal ini menunjukan tingkat dekomposisi yang sangat tinggi sehingga laju produksi nitrat cepat tersedia bagi tanaman. Pupuk kandang berperan dalam memperbaiki kesuburan tanah. Unsur-unsur hara yang terdapat pada pupuk kandang sapi yakni $\mathrm{N}$ 2,33 \%, $\mathrm{P}_{2} \mathrm{O}_{5}$ 0,61 \%, $\mathrm{K}_{2} \mathrm{O}$ 1,58 \%, Ca 1,04 \%, Mg 0,33\%, Mn 179 ppm dan Zn 70,5 ppm (Andayani dan Lasarindo, 2013).

Penggunaan pupuk kimia secara berlebihan dapat membawa dampak negatif pada fungsi ekologis dan karakteristik biokimia dalam tanah, termasuk kehilangan unsur hara tanah dan pengasaman tanah di perkebunan teh (Yang et. al., 2018). Jika dibandingkan dengan pupuk kimia, pemupukan organik di perkebunan teh dapat meningkatkan kesuburan tanah dan mencapai akumulasi karbon, yang merupakan faktor kunci dalam menentukan sifat tanah dan produktivitas dan meningkatkan keanekaragaman mikroba tanah (Qiu et. al., 2014; Wang et. al., 2017; Ji et. al., 2018; Gu et. al., 2019). Pemanfaatan kompos tea fluff merupakan salah satu upaya dalam pengurangan penggunaan pupuk kimia. Aplikasi limbah pengolahan pabrik (tea fluff) pada tanaman muda di Srilanka memberikan hasil pertumbuhan yang paling baik dibandingkan dengan aplikasi bahan organik lainnya (Widayat et. al., 2002).
Bhardwaj et. al. (1998) telah menerapkan manajemen limbah di perkebunan teh India untuk memperbaiki sifat dan produktivitas tanah. Fungsi pemberian kompos tea fluff dalam jangka pendek dapat meyumbangkan hara untuk tanaman dan jangka panjang akan memperbaiki perakaran tanaman teh. Penelitian ini bertujuan untuk mengolah dan memanfaatkan limbah pabrik teh (tea fluff) yang dapat digunakan sebagai kompos bagi tanaman teh serta mendapatkan komposisi pengomposan limbah pabrik teh (tea fluff) yang terbaik dengan menggunakan kombinasi EM4 dan pupuk kandang sapi.

\section{METODOLOGI}

Penelitian telah dilakukan di Rumah Kompos Kebun Percobaan Pusat Penelitian Teh dan Kina, Gambung, Jawa Barat selama 5 minggu. Lokasi percobaan terletak pada ketinggian $1.350 \mathrm{~m}$ dpl dengan jenis tanah Andisol. Metode penelitian menggunakan Rancangan Acak Kelompok (RAK) yang terdiri dari 6 perlakuan dan ulangan 4 kali, sehingga terdapat 24 satuan percobaan. Perlakuan merupakan perbandingan komposisi tea fluff dan pupuk kandang, yang terdiri atas:

$$
\begin{aligned}
& \text { P0 }=\text { Kontrol (tea fluff segar) } \\
& \text { P1 }=\text { Tea Fluff }+ \text { pukan }(1: 1) \\
& \text { P2 }=\text { Tea Fluff }+ \text { pukan }(1: 2) \\
& \text { P3 }=\text { Tea Fluff }+ \text { pukan }(1: 3) \\
& \text { P4 = Tea Fluff }+ \text { pukan }(2: 1) \\
& \text { P5 }=\text { Tea Fluff }+ \text { pukan }(3: 1)
\end{aligned}
$$

Kompos yang telah matang akan dianalisa di laboratorium dan hasil tersebut dibandingkan dengan Standar Kualitas Kompos SNI: 197030-2004 (BSN, 2004). Parameter yang diamati pada penelitian ini yaitu pengamatan $\mathrm{pH}$ dan suhu kompos menggunakan $\mathrm{pH}$ meter dan termometer. Pengamatan dilakukan setiap 2 hari sekali pada bak kompos sebanyak 5 titik yang diambil secara diagonal (Gambar 1). Analisis sifat kimia pada kompos matang dilakukan pada parameter $\mathrm{pH}, \mathrm{C}$-Organik, $\mathrm{C} / \mathrm{N}$ ratio dan $\mathrm{N}$ total. Analisis kompos dilakukan di Laboratorium Balai Tanaman Sayuran (Balitsa). 


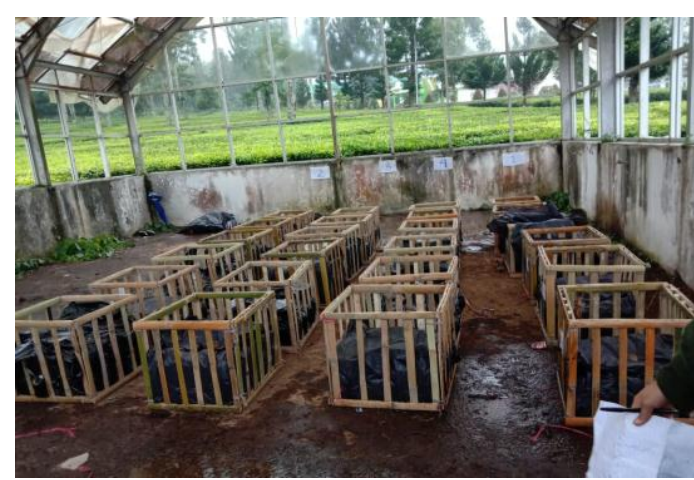

a

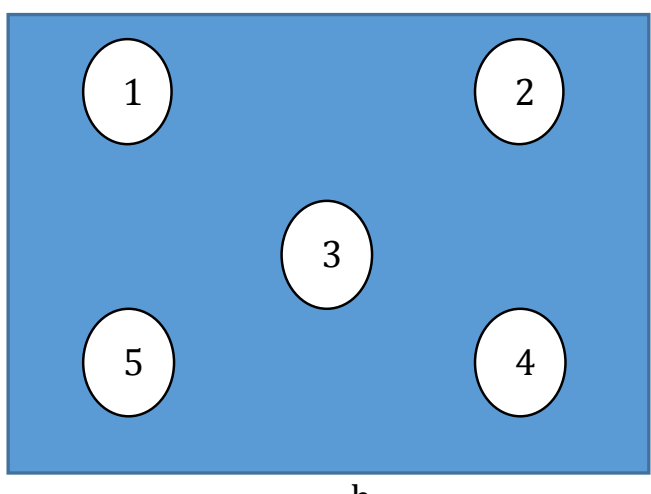

b

Gambar 1 Susunan bak kompos (a); Titik pengamatan kompos (b)

Tahapan pengomposan tea fluff teh hijau dapat diuraikan sebagi berikut: tea fluff dan pupuk kandang ditimbang sesuai dengan perbandingan pada setiap perlakuan. Berat masing-masing kombinasi perlakuan sebesar $20 \mathrm{~kg}$. Bahan tea fluff dan pupuk kandang dicampur sampai rata, kemudian di beri larutan EM-4 sebanyak 2,5 liter pada setiap perlakuan bahan kompos. Bahan kompos dimasukkan ke dalam bak kompos (ukuran 50 x 50 x $50 \mathrm{~cm}$ ) yang telah disiapkan dengan ketinggian 15-20 cm dan ditutup rapat dengan plastik. Kandungan air dipertahankan tidak lebih dari 30\%, yang ditandai dengan bahan

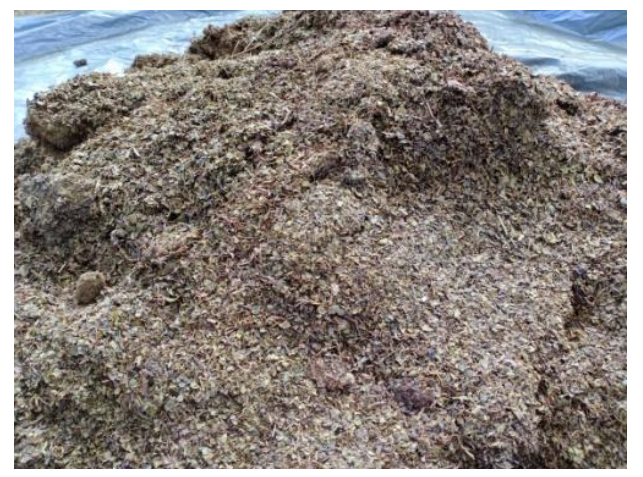

a kompos bila dikepal dengan tangan air tidak keluar dari bahan kompos.

Fermentasi bahan kompos selama 14-35 hari sampai kompos matang Suhu kompos harian dipertahankan $40-50^{\circ} \mathrm{C}$, jika suhu $>50^{\circ} \mathrm{C}$ maka dilakukan pembalikan kompos, setelah itu kompos ditutup kembali. Standar keberhasilan dekomposisi adalah: temperatur stabil pada suhu $30-35^{\circ} \mathrm{C}$, aroma tidak berbau, dan kelembaban optimal berkisar antara 40-50\%. Berdasarkan kenampakan fisik, warna kompos yang telah matang lebih gelap (hitam) dibanding dengan limbah tea fluff teh hijau (Gambar 2).

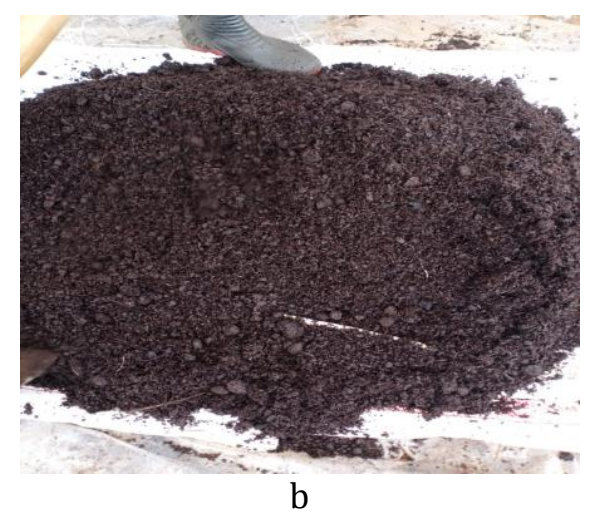

Gambar 2 Limbah tea fluff teh hijau (a) dan kompos tea fluff matang (b)

\section{HASIL DAN PEMBAHASAN}

\subsection{Suhu dan pH Kompos Tea Fluff}

Data fluktuasi suhu dan pH harian pada proses pembuatan kompos tea fluff dan pupuk kandang sapi dengan bioaktivator EM4 ditampilkan dalam Gambar 3 dan 4. Gambar 3 memperlihatkan pengomposan pada semua perlakuan mulai mengalami kenaikan suhu pada kisaran hari ke 3 dan suhu tertinggi (40 - $46^{\circ} \mathrm{C}$ ) pada hari ke 10 sampai 12 . Peningkatan suhu kompos dikarenakan adanya aktivitas mikroorganisme pengurai yang tinggi. Peningkatan suhu dapat disebabkan adanya panas hasil metabolisme mikroorganisme pengurai, yakni merupakan hasil respirasi dan mikrorganisme yang hidup di dalam media kompos tersebut. 


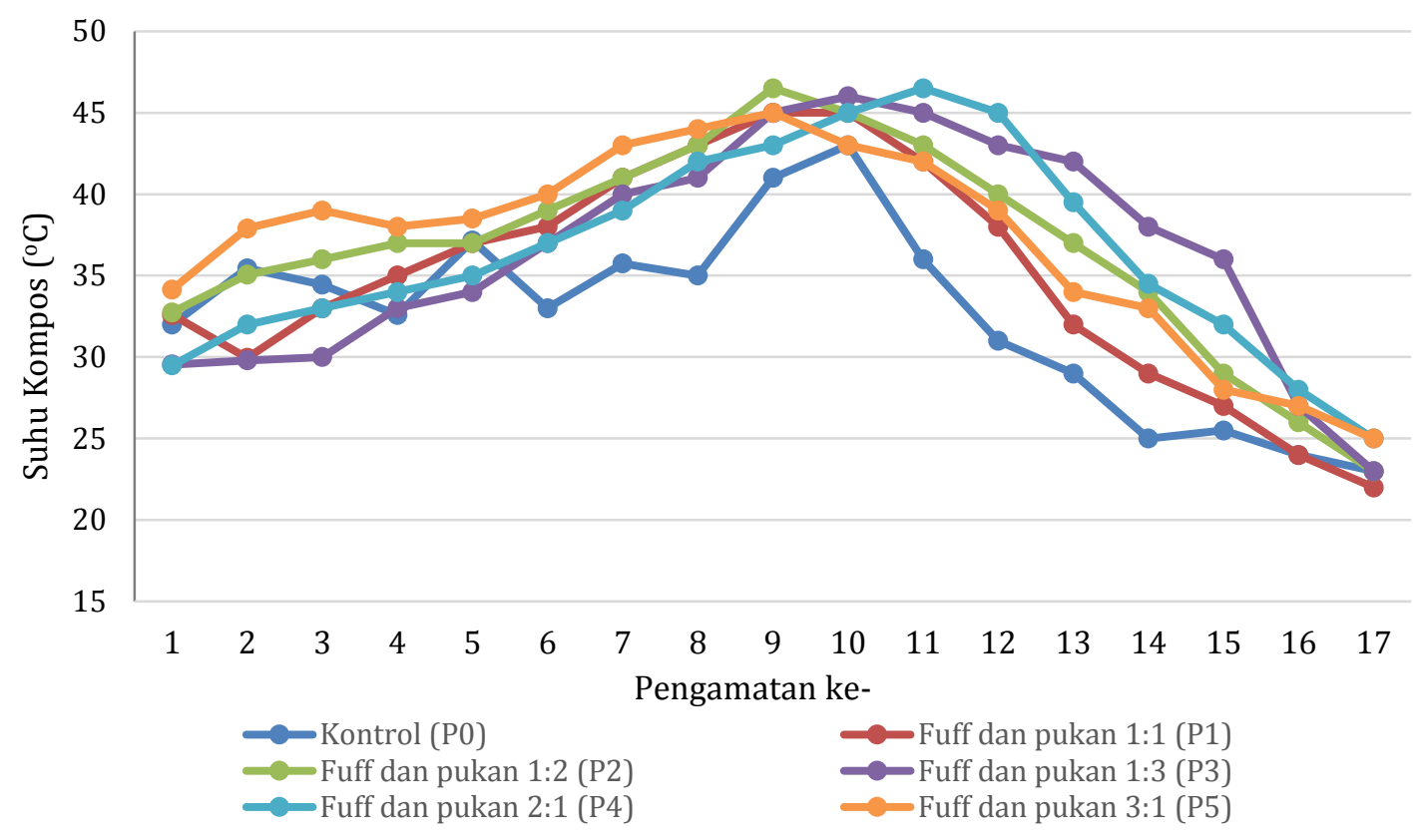

Gambar 3 Fluktuasi suhu selama proses pematangan kompos pada semua perlakuan

Ruskandi (2006) menyatakan bahwa terdapat dua fase pengomposan secara aerobik yaitu fase mesofilik $23-45^{\circ} \mathrm{C}$ dan fase termofilik 45-65 ${ }^{\circ} \mathrm{C}$. Peranan mikroorganisme termofilik mulai aktif dengan mendegradasi bahan organik pada awal hingga pertengahan, sedangkan mikroorganisme termofilik berperan dalam proses pematangan kompos (Cahaya dan Nugroho, 2008). Pengaruh adanya mikroorganisme mesofilik dan termofilik ini dapat dilihat pada fluktuasi suhu selama proses pengomposan (Pratiwi, 2013). Salah satu ciri kompos yang mulai matang adalah ditandai dengan penurunan suhu, hal ini terjadi karena bahan organik yang dapat diuraikan oleh mikroorganisme mulai berkurang (Suwatanti dan Widiyaningrum, 2017).

Kadar air dalam pengomposan berpengaruh terhadap waktu lamanya pengomposan. Mikroorganisme pengurai dapat bekerja optimal pada kisaran kadar air dalam kompos sebesar 40 \%. Kadar air dalam bahan kompos akan megalami penurunan, hal ini disebabkan adanya proses penguapan bahan organik oleh mikroorganisme dan pembalikan kompos. Proses pembalikan bertujuan agar kompos tidak terlalu lembab, kadar air menurun, dan dapat mengakibatkan fluktuasi temperatur selama prsose pengomposan (Pandebesie dan
Rayuanti, 2013). Kelembaban berperan dalam suplai oksigen dan proses metabolism mikroba yang sangat berpengaruh dalam pengomposan. Menurut Trivana dan Pradana (2017) proses pengomposan lebih lama dapat disebabkan karena kompos terlalu lembab sehingga degradasi bahan organik menjadi lambat dalam dekomposisi mikroorganisme.

Hasil pengamatan $\mathrm{pH}$ harian dalam proses pengomposan menunjukkan fluktuasi $\mathrm{pH}$ mulai dari kisaran 4,8-7 (Gambar 4). Pada semua perlakuan di awal pengomposan terjadi penurunan $\mathrm{pH}$ atau $\mathrm{pH}$ masam $(\mathrm{pH}<6)$. Hal tersebut terjadi disebabkan mikroba menguraikan bahan organik menjadi senyawasenyawa organik (Syafrudin dan Zaman, 2007; Supadma dan Arthagama, 2008), diikuti peningkatan $\mathrm{pH}$ akibat protein yang terurai dan terjadinya pelepasan amonia. Degradasi bahan-bahan organik ditunjukkan dengan adanya perubahan $\mathrm{pH}$ selama proses pengomposan berlangsung (Ismayana et. al., 2012).

Berdasarkan Gambar 4, kenaikkan $\mathrm{pH}$ terjadi pada pengamatan ke-4 sampai 12 dan stabil hingga pada pengamatan ke-17, pH sudah menunjukkan netral $(\mathrm{pH} 7)$. Nilai $\mathrm{pH}$ kompos ideal antara 6,8 hingga maksimum 7,49 (SNI: 19-7030-2004). Pada semua perlakuan, nilai $\mathrm{pH}$ normal dapat dilihat mulai 
dari pengamatan ke-7 hingga kompos matang, hal ini dinilai sudah memenuhi kriteria standar SNI 19-7030-2004 (BSN, 2004). Pada kisaran $\mathrm{pH}$ ini pemecahan polimer-polimer menjadi asam-asam organik oleh mikroorganisme pengurai berjalan dengan normal. Kompos dengan $\mathrm{pH}$ netral akan sangat bermanfaat dalam mengurangi keasaman tanah, selain itu, pada $\mathrm{pH}$ ini unsur hara mudah diserap oleh tanaman (Astari, 2011).

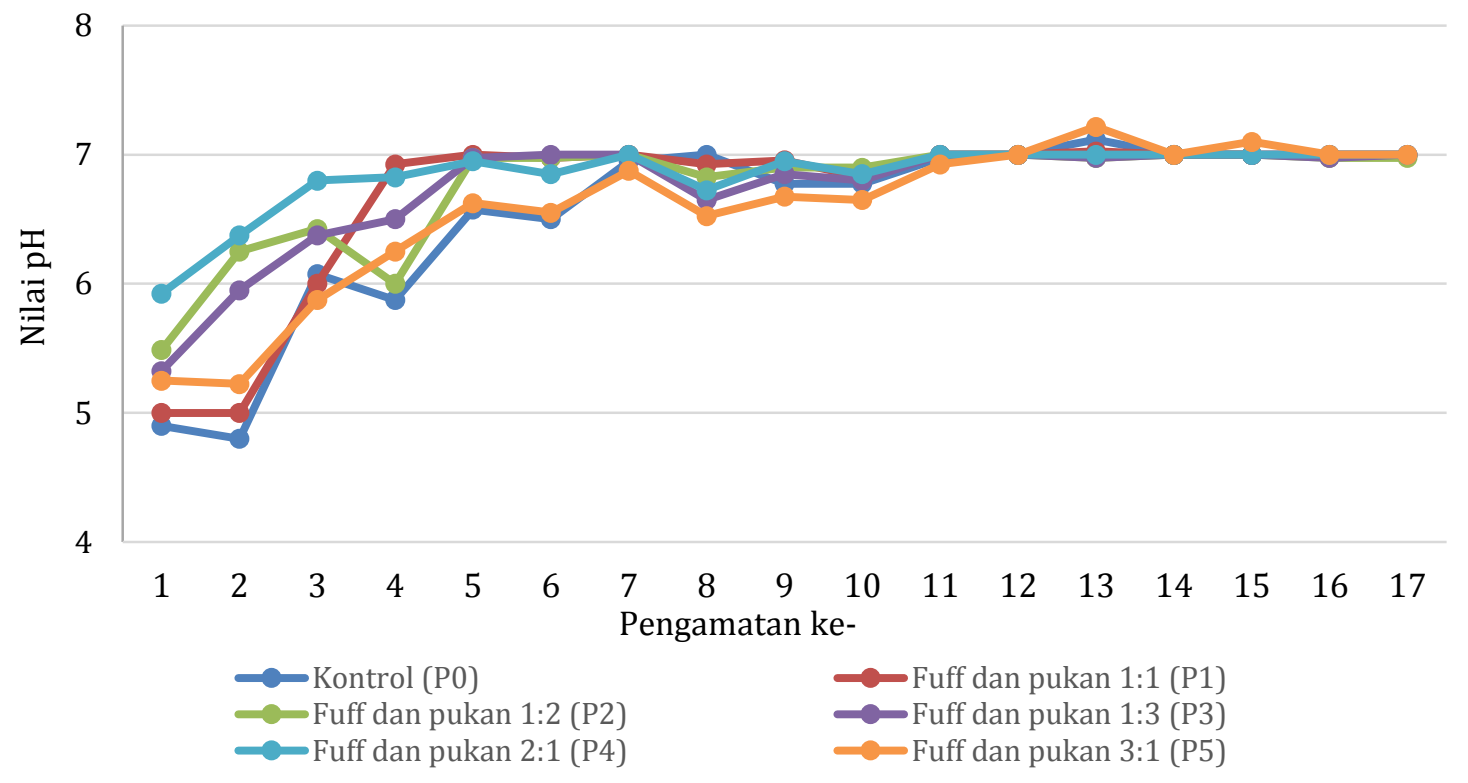

Gambar 4 Fluktuasi pH selama proses pematangan kompos pada semua perlakuan

Hasil pengamatan $\mathrm{pH}$ harian dalam proses pengomposan pada gambar 4 menunjukkan fluktuasi pH mulai dari kisaran 4,8-7. Pada semua perlakuan di awal pengomposan terjadi penurunan $\mathrm{pH}$ atau $\mathrm{pH}$ masam $(\mathrm{pH}<6)$. Hal tersebut terjadi disebabkan mikroba menguraikan bahan organik menjadi senyawasenyawa organik (Syafrudin dan Zaman, 2007; Supadma dan Arthagama, 2008), diikuti peningkatan $\mathrm{pH}$ akibat protein yang terurai dan terjadinya pelepasan amonia. Degradasi bahan-bahan organik ditunjukkan dengan adanya perubahan $\mathrm{pH}$ selama proses pengomposan berlangsung (Ismayana et. al., 2012).

Berdasarkan Gambar 4, kenaikkan pH terjadi pada pengamatan ke-4 sampai 12 dan stabil hingga pada pengamatan ke-17, $\mathrm{pH}$ sudah menunjukkan netral ( $\mathrm{pH} 7$ ). Nilai $\mathrm{pH}$ kompos ideal antara 6,8 hingga maksimum 7,49 (Standar kualitas kompos SNI: 19-70302004). Pada semua perlakuan, nilai pH normal dapat dilihat mulai dari pengamatan ke-7 hingga kompos matang, sudah memenuhi kriteria standar kompos SNI. Pada kisaran $\mathrm{pH}$ ini pemecahan polimer-polimer menjadi asam- asam organik oleh mikroorganisme pengurai berjalan dengan normal. Nilai pH netral akan mudah diserap oleh tanaman, dan berguna untuk mengurangi keasaman tanah (Astari, 2011).

Menurut Djuarnani et. al. (2005), laju pengomposan dipengaruhi oleh beberapa faktor yaitu: ukuran bahan kompos, kelembaban kompos (proses dekomposisi secara aerobik akan berlangsung dengan baik pada kelembaban sekitar 50-60\%), aerasi (kebutuhan oksigen dalam pembuatan kompos adalah 10$18 \%$ atau paling sedikit 50\%); temperatur (temperatur optimum pengomposan adalah 35 $-55^{\circ} \mathrm{C}$ ), $\mathrm{pH}$ (pH optimal kompos adalah $6-8$ ) dan mikroorganisme.

\subsection{Karakteristik Fisik Kompos}

Berdasarkan karakteristik kompos tea fluff yang sudah matang (Tabel 1) dan fisik kompos pada setiap perlakuan (Gambar 6), bahwa pada keseluruhan kompos matang dalam waktu 4-5 minggu. Menurut Syafrudin dan Zaman (2007) kompos matang mempunyai karakteristik sebagai berikut: berbau seperti tanah, warna 
coklat kehitam-hitaman, bentuk fisik telah hancur, pH netral, penurunan berat lebih dari $60 \%$ dari berat awal, rasio $\mathrm{C} / \mathrm{N} 10-20$, dan tidak mengandung bahan-bahan asing. Menurut Sulistyawati et. al. (2008), kualitas fisik kompos adalah gambaran mengenai kemampuan dekomposer dalam peruraian bahan-bahan organik.

Pada saat bahan-bahan organik yang mulai terdegradasi oleh mikroorganisme, maka pada saat itu pula warna kompos akan menjadi coklat kehitaman. Perubahan ini diikuti dengan bau campuran bahan organik lain seperti kotoran sapi juga akan hilang dan akan berbau seperti tanah. Selain itu, tekstur kompos sudah menunjukkan seperti tanah. Ciri-ciri tersebut menunjukkan kualitas kompos yang baik (Ismayana et. al., 2012).

Tabel 1 Karakteristik fisik kompos yang sudah matang

\begin{tabular}{ccccc}
\hline $\begin{array}{c}\text { Perla- } \\
\text { kuan }\end{array}$ & Warna & Bau & $\begin{array}{c}\text { Suhu } \\
\left({ }^{\circ} \mathrm{C}\right)\end{array}$ & $\mathrm{pH}$ \\
\hline P0 & Hitam & Tidak Berbau & 23,40 & 7 \\
P1 & Hitam & Tidak Berbau & 21,60 & 7 \\
P2 & Hitam & Tidak Berbau & 23,10 & 7 \\
P3 & Hitam & Tidak Berbau & 24,3 & 7 \\
P4 & Hitam & Tidak Berbau & 23,0 & 7 \\
P5 & Hitam & Tidak Berbau & 23,7 & 7 \\
\hline
\end{tabular}

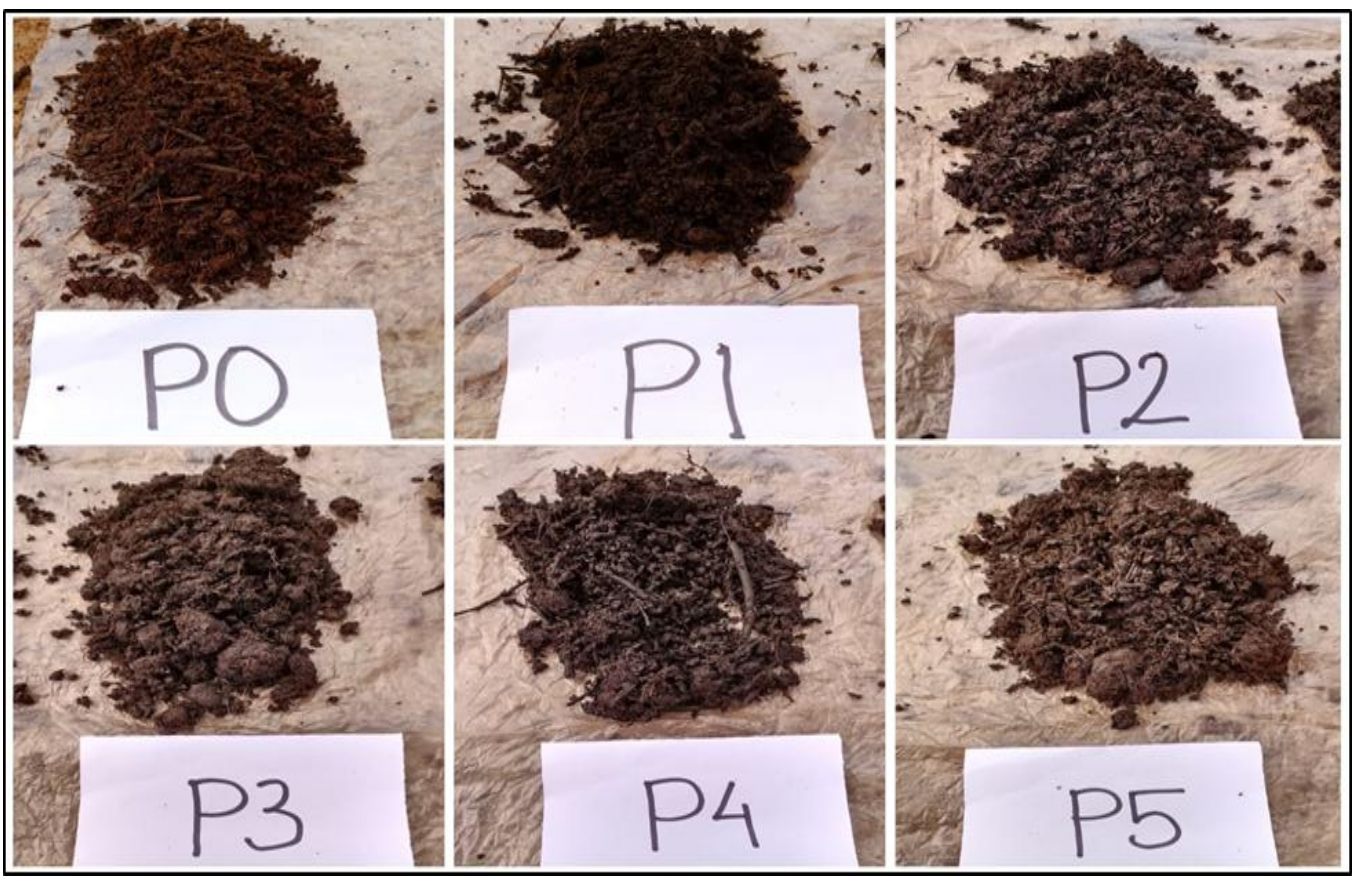

Gambar 6 Kenampakan kompos matang pada masing-masing perlakuan

\subsection{Sifat Kimia Kompos}

Hasil analisa statistik pada hasil analisa kompos tea fluff (Tabel 2), menunjukkan hasil perbedaan nyata pada parameter $\mathrm{pH}$ kompos, C-organik dan N-total kompos, namun pada $\mathrm{C} / \mathrm{N}$ rasio tidak menunjukkan perbedaan nyata. Hasil analisa kompos menunjukkan semua parameter masuk ke dalam kriteria SNI (BSN, 2004), Hal ini ditunjukkan dengan nilai $\mathrm{C} / \mathrm{N}$ rasio yang memenuhi syarat kematangan kompos yaitu berkisar 10,5-13.
Keberhasilan proses pengomposan dapat dilihat pada nilai $\mathrm{C} / \mathrm{N}$ rasio dimana, nilai $\mathrm{C} / \mathrm{N}$ kompos sama dengan rasio $\mathrm{C} / \mathrm{N}$ tanah, $\mathrm{C} / \mathrm{N}$ rasio kompos matang adalah 10-20 (Syafrudin dan Zaman, 2007). Rasio C/N merupakan perbandingan antara banyaknya kandungan unsur karbon (C) terhadap banyaknya kandungan unsur nitrogen $(\mathrm{N})$ yang ada pada suatu bahan organik. Mikroorganisme membutuhkan karbon dan nitrogen untuk aktivitas hidupnya. $\mathrm{C} / \mathrm{N}$ rasio yang terkandung didalam kompos menggambarkan tingkat kematangan 
dari kompos tersebut, semakin tinggi nilai $\mathrm{C} / \mathrm{N}$ rasio di dalam kompos menunjukkan kompos belum terurai secara sempurna atau belum matang (Surtinah, 2003; Purnomo et. al., 2017). Kompos yang memiliki nilai $\mathrm{C} / \mathrm{N}<20$ artinya telah terjadi perombakan dan mineralisasi unsur-unsur hara yang terdapat dalam bahanbahan limbah organik tersebut, sehingga unsur hara dapat lebih tersedia bagi tanaman (Hanafiah, 2005).

Tabel 2 Hasil analisa sifat kimia kompos tea fluff

\begin{tabular}{lccccccc}
\hline & & \multicolumn{7}{c}{ Perlakuan } \\
\cline { 3 - 8 } Parameter & SNI & $\begin{array}{c}\text { Kontrol } \\
\text { (P0) }\end{array}$ & $\begin{array}{c}\text { Fuff dan } \\
\text { pukan 1:1 } \\
\text { (P1) }\end{array}$ & $\begin{array}{c}\text { Fuff dan } \\
\text { pukan 1:2 } \\
\text { (P2) }\end{array}$ & $\begin{array}{c}\text { Fuff dan } \\
\text { pukan 1:3 } \\
\text { (P3) }\end{array}$ & $\begin{array}{c}\text { Fuff dan } \\
\text { pukan 2:1 } \\
\text { (P4) }\end{array}$ & $\begin{array}{c}\text { Fuff dan } \\
\text { pukan 3:1 } \\
\text { (P5) }\end{array}$ \\
\hline pH H $\mathrm{H}_{2} \mathrm{O}$ & $6,8-7,49$ & $7,15 \mathrm{abc}$ & $6,68 \mathrm{a}$ & $7,28 \mathrm{bc}$ & $7,2 \mathrm{abc}$ & $7,68 \mathrm{c}$ & $7,08 \mathrm{ab}$ \\
C-Organik (\%) & $9,8-32$ & $18,1 \mathrm{ab}$ & $17,05 \mathrm{a}$ & $17,47 \mathrm{ab}$ & $16,18 \mathrm{a}$ & $17,77 \mathrm{ab}$ & $20,61 \mathrm{~b}$ \\
N-total (\%) & min 0,4 & $1,75 \mathrm{~cd}$ & $1,49 \mathrm{abc}$ & $1,32 \mathrm{ab}$ & $1,26 \mathrm{a}$ & $1,56 \mathrm{bcd}$ & $1,835 \mathrm{~d}$ \\
C/N & $10-20$ & 10,5 & 11,5 & 13,25 & 13 & 11,25 & 11,25 \\
\hline
\end{tabular}

Keterangan: Angka yang diikuti huruf yang sama pada baris dan kolom yang sama menunjukkan perlakuan tidak berbeda nyata berdasarkan uji jarak berganda Duncan dengan tingkat signifikasi 0,05\%.

Berdasarkan Tabel 2, perlakuan P5 (kombinasi tea fluff : pukan $(3: 1)$ menunjukkan nilai C-organik dan $\mathrm{N}$-total tertinggi. Menurut Rahayu dan Nurhayati (2005), kandungan hara limbah padat teh memiliki nilai C-organik $(5,23 \%)$ dan $\mathrm{N}$-total $(0,11 \%)$. Sesuai dengan perlakuan P5 (kompos tea fluff:pukan = 3:1) dimana perbandingan jumlah tea fluff lebih besar dibanding jumlah pukan, menghasilkan kandungan $\mathrm{C}$-organik dan $\mathrm{N}$-total lebih tinggi dibandingkan pada kombinasi perlakuan lainnya. Hal ini disebabkan rasio $\mathrm{C} / \mathrm{N}$ pupuk kandang sapi yang rendah, dimana bahanbahan kompos tersebut mudah melapuk dan menghasilkan unsur nitrogen untuk tanaman (Siregar dan Dewi, 2020).

Menurut Wijaksono et. al. (2016) Nitrogen pada pupuk kandang dalam bentuk $\mathrm{NH}^{+}$dan asam amino yang dimanfaatkan oleh bakteri sebagai sumber energi. Nitrogen merupakan komponen penting sebagai penyusun protein dan $50 \%$ biomasa bakteri tersusun dari protein. Sehingga semakin banyak kandungan bakteri maka semakin tinggi kandungan Nitrogen. Selain itu, pemberian kotoran sapi tidak hanya dapat meningkatkan keanekaragaman bakteri tanah, tetapi juga secara efektif mengatur struktur komunitas bakteri tanah di perkebunan teh (Zhang et. al., 2020).

\section{KESIMPULAN}

Parameter fisik (warna, bau, dan tekstur) telah menunjukkan kompos tea fluff matang pada semua perlakuan dalam waktu 5 minggu. Berdasarkan hasil analisa kompos tea fluff, terdapat perbedaan nyata pada $\mathrm{pH}$ kompos, Corganik dan $\mathrm{N}$-total kompos. Pada seluruh parameter kimia kompos telah memenuhi standar ideal kualitas kompos sesuai kriteria SNI 19-7030-2004. Perlakuan kombinasi tea fluff: pukan (3:1) menunjukkan hasil C-organik dan N-total tertinggi di antara semua perlakuan.

\section{DAFTAR PUSTAKA}

Amalia, D. dan Widiyaningrum, P. 2016. Penggunaan EM4 dan MOL limbah tomat sebagai bioaktivator pada pembuatan kompos. Life Science 5 (1): 18-24.

Andayani dan Sarido, L. 2013. Uji empat jenis pupuk kandang terhadap pertumbuhan dan hasil tanaman cabai keriting (Capsicum annum L.). Jurnal AGRIFOR. 12(1): 22-29.

Astari, L. P. 2011. Kualitas Pupuk Kompos Bedding Kuda dengan Menggunakan Aktivator Mikroba yang Berbeda. IPB Bogor. [Skripsi]. 
Bhardwaj, K. K. R., N. K. Kalyansundaram dan H. H. Khan. 1998. Management of organic materials from field and plantation crops. Bull. Indian Soil Sci. 19: 122-134.

BSN [Badan Standarisasi Nasional]. 2004. Spesifikasi Kompos dari Sampah Organik Domestik SNI 19-70302004.

Cahaya T.S., Andhika dan D.A. Nugroho. 2009 Pembuatan kompos dengan menggunakan limbah padat organik Dalam Seminar Tugas Akhir S1 Jurusan Teknik Kimia UNDIP. Jurusan Teknik Kimia UNDIP. Semarang.

Djuarnani, N., Kristian, dan B. Setiawan. 2005. Cara Cepat Membuat Kompos. Agro Media Pustaka. Jakarta.

Gu, S., Q. Hu, Y. Cheng, L. Bai, Z. Liu, W. Xiao, Z. Gong, Y. Wu, K. Feng, Y. Deng. Application of organic fertilizer improves microbial community diversity and alters microbial network structure in tea (Camellia sinensis) plantation soils. Soil Tillage Res. 195:104356.

Ismayana A., N.S. Indrasti, Suprihatin, A. Maddu, and A. Fredy. 2012. Faktor rasio $\mathrm{C} / \mathrm{N}$ awal dan laju aerasi pada proses cocomposting bagasse dan blotong. J. Tekn. Industri Pertanian. 22(3): 173-179.

Hanafiah, K.A. 2005. Dasar-dasar Ilmu Tanah. Raja Grafindo Persada. Jakarta.

Ji, L., Z. Wu, You Z, Yi X, Ni K, Guo S, Ruan J. 2019. Effects of organic substitution for synthetic $\mathrm{N}$ fertilizer on soil bacterial diversity and community composition: a 10-year field trial in a tea plantation. Agric Ecosyst Environ. 268:124-132.

Kurniawan, D., Sri K dan N. M. Sabrina. 2017. Pengaruh volume penambahan effective microorganism 4 (EM4) $1 \%$ dan lama fermentasi terhadap kualitas pupuk bokashi dari kotoran kelinci dan limbah nangka. Jurnal Industria. 2(1): 57-66.

Muningsih, R., dan Ciptadi, G. 2018. Analisis kandungan unsur hara limbah cair teh hijau sebagai bahan pupuk organic pada bibit teh. Mediagro
Jurnal Ilmu-Ilmu Pertanian. 14(1): 25-32.

Pandebesie, E. S. dan Rayuanti, D. 2013. Pengaruh penambahan sekam pada proses pengomposan sampah domestik. Jurnal Lingkungan Tropis. 6(1):31-40.

Pratiwi, I. G. A. P., I. W. D. Atmaja, dan N. N. Soniari. 2013. Analisis kualitas kompos limbah persawahan dengan mol sebagai dekomposer. E-Jurnal Agroteknologi Tropika. 2(4): 195203.

Purnomo, E. A., E, Sutrisno dan S. Sumiyati. 2017. Pengaruh variasi $\mathrm{C} / \mathrm{N}$ rasio terhadap produksi kompos dan kandungan kalium $(\mathrm{K})$, pospat $(\mathrm{P})$ dari batang pisang dengan kombinasi kotoran sapi dalam sistem vermicomposting. Jurnal Teknik Lingkungan. 6(2): 1 - 15.

Qiu, S., Wang, L, Huang, D, Lin, X. 2014. Effects of fertilization regimes on tea yields, soil fertility, and soil microbial diversity. Chilean J Agric Res. 74:3339.

Rahayu, M. dan Nurhayati. 2005. Penggunaan EM-4 dalam pengomposan limbah teh padat. Jurnal Penelitian Bidang Ilmu Pertanian. 3(2): 26-30.

Ruskandi. 2006. Teknik pembuatan kompos limbah kebun pertanaman kelapa polikultur. Buletin Teknik Pertanian. 11(1): $33-36$.

Siregar, M. R. I dan Dewi, R. K. 2020. Pembuatan kompos menggunakan tumbler di Desa Karanggatak Kabupaten Boyolali. Jurnal Pusat Inovasi Masyarakat. 2(3): 338-343.

Sulistyawati, E., N. Mashita, dan D. Choesin. 2008. Pengaruh agen dekomposer terhadap kualitas hasil pengomposan sampah organik rumah tangga. Dalam Seminar Nasional Penelitian Lingkungan di Perguruan Tinggi. Universitas Trisakti : Jakarta.

Sulistyorini, L. 2005. Pengelolaan sampah dengan cara menjadikannya kompos. Jurnal Kesehatan Lingkungan. 2(1): 77-84.

Suwatanti, E. P. S. dan Widiyaningrum, P. 2017. Pemanfaatan MOL limbah sayur pada 
proses pembuatan kompos. Jurnal MIPA. 40(1): 1-6.

Supadma, A. A. N. dan Arthagama, D. M. 2008. Uji formulasi kualitas pupuk kompos yang bersumber dari sampah organik dengan penambahan limbah ternak ayam, sapi, babi, dan tanaman pahitan. Jurnal Bumi Lestari. 8(2): 113-121.

Surtinah. 2013. Pengujian kandungan unsur hara dalam kompos yang berasal dari serasah tanaman jagung manis (Zea mays saccharata). Jurnal Ilmiah Pertanian. 11(1): 16-26.

Syafrudin dan Zaman, B. 2007. Pengomposan limbah teh hitam dengan penambah kotoran kambing pada variasi yang dengan berbeda menggunakan stater EM4. Jurnal TEKNIK. 28 (2): 125 131.

Trivana, L. dan Pradhana, A. Y. 2017. Optimalisasi waktu pengomposan dan kualitas pupuk kandang dari kotoran kambing dan debu sabut kelapa dengan bioaktivator PROMI dan orgadec. Jurnal Sains Veteriner. 35 (1): 136 - 144.

Wang J., Y. Song, T. Ma, W. Raza, J. Li, J.G. Howland, Q. Huang, Q. Shen. 2017. Impacts of inorganic and organic fertilization treatments on bacterial and fungal communities in a paddy soil. Appl Soil Ecol. 112:42-50.

Widayat, W., D. J. Rayati, I. S. Arifin, Sudjatmoko dan O. Suherman. 2002. Optimalisasi lahan teh dengan inokulasi cendawan mikoriza arbuskula dan pemberian kompos pluff dalam rangka menunjang pertanian organik. Dalam Laporan Hasil Penelitian Pusat Penelitian Teh dan Kina. Hal: 203210.

Wijaksono, R. A., R. Subiantro dan B. Utoyo. 2016. Pengaruh lama fermentasi pada kualitas pupuk kandang kambing. Jurnal Agro Industri Perkebunan. 4(2): 88-96.

Yang X, K. Ni, Y. Shi, X. Yi, Q. Zhang, L. Fang, L. Ma, J. Ruan. 2018. Effects of long-term nitrogen application on soil acidification and solution chemistry of a tea plantation in China. Agric Ecosyst Environ. 252:74-82.
Zhang, S., L. Sun, Y. Wang, K. Fan, Q. Xu, Y. Li. Q. Ma, J. Wang, W. Ren, and Z. Ding. 2020. Cow manure application effectively regulates the soil bacterial community in tea plantation. BMC Microbiology. 20(1): 190. 